\title{
PIPELE DE LUT DESCOPERITE LA ORAŞUL DE FLOCI, COMUNA GIURGENI, JUD. IALOMIȚA
}

\section{CLAY PIPES DISCOVERED AT ORAȘUL DE FLOCI, GIURGENI, IALOMITA COUNTY}

This article presents sixteen clay pipes discovered at Oraşul de Floci, Giurgeni, Ialomița County. They were found in 2008 and 2009 , in archaeological contexts dated to the $16^{\text {th }}-17^{\text {th }}$ c., along with other elements relevant for chronology: stratigraphy and currency. General criteria for cataloging were established following the smoking pipes from Babadag. Also, there were undertaken further researches in the smoking pipes collections of MNIR and other museums, to highlight specific features.

KEYWORDS: clay tobacco pipes, Oraşul de Floci, 16-17century, tobacco, archaeological contexts CUVINTE CHEIE: pipe de lut, Orașul de Floci, secolele XVI-XVII, tutun, context arheologic

Cercetarea arheologică a sitului de la Oraşul de Floci, începută acum aproape 40 de ani, a fost adusă la cunoștința specialiștilor în special prin intermediul rapoartelor de săpătură anuale și comunicărilor din cadrul sesiunilor științifice ${ }^{1}$. Despre oraşul medieval aflat la vărsarea Ialomiței în Dunăre au fost publicate articole punctuale cu referire la edificiile laice și religioase de aici $^{2}$, la obiectele specifice habitatului urban descoperite ${ }^{3}$, precum și la diferitele aspecte ce privesc viața cotidiană a locuitorilor săi ${ }^{4}$.

Cu siguranță specificul acestui oraș este dat de rolul său de târg, fapt evidențiat de cercetarea arheologică. Activitatea comercială este bine documentată prin cantitatea mare de monede autohtone, dar și străine, ceramica de import, în special cea produsă în atelierele din Imperiul Otoman și cunoscută în general sub denumirea de „ceramică de Iznick”, precum şi obiectele de podoabă, accesorii ce provin din ateliere situate în afara orașului şi chiar a Țării Românești.

Dacă toate aceste aspecte au făcut obiectul unor studii de specialitate, aşa cum am menționat anterior, o categorie de materiale a rămas în afara preocupărilor specialiștilor, respectiv pipele de lut. Preocupările sunt recente în ceea ce privește studiul pipelor de lut în spațiul românesc în general ${ }^{5}$, deși fumatul a fost practicat aici în aceeaşi manieră ca în lumea europeană. Fumatul și dezvoltarea unor ateliere meșteșugărești în care erau realizate pipele a cunoscut o evoluție începând cu ultimul sfert al secolului al XVI-lea. Răspândirea acestui obicei în Europa a fost facilitată de dezvoltarea comerțului și avântul circulației mărfurilor din această perioadă. Pipele descoperite pe teritoriului fostului Imperiu Otoman au fost studiate, analizate şi publicate de către specialiști, acest fapt datorându-se şi cercetării arheologice complexe a

\footnotetext{
${ }^{1}$ Chițescu et alii 1979; Chițescu et alii 1981; Chiţescu et alii 1982; Chițescu, Păunescu, Papasima 1983; Chițescu, Păunescu 1986; Păunescu 2000; Păunescu 2001; Păunescu 2005; Păunescu et alii 2010. Vezi şi rapoartele anuale publicate în CCA, din anii 2006, 2007, 2008, 2009, 2010 (disponibile și on line).

2 Chiţescu et alii 1979; Chiţescu et alii 1981; Chițescu et alii 1982; Chiţescu, Păunescu, Papasima 1983

${ }^{3}$ Lungu I981; Costea-Ene 2003-2004

${ }^{4}$ Păunescu 2003; Păunescu 2005

${ }^{5}$ Gruia 2012; Costea, Stănică, Ignat 2007
} 
siturilor de aici. De asemenea, studii despre pipele de lut sunt publicate lunar în reviste de specialitate $^{6}$.

Tutunul, precum și obiceiul de a fuma, au fost atestate în Europa încă de la sfârșitul secolului al XVI-lea și inițial acesta a fost interzis chiar în Imperiul Otoman ${ }^{7}$. Folosit ca plantă medicinală, dar și ca otravă, provenită din America de Sud, tutunul este subiectul unei povești interesante. Planta a fost adusă în Spania de către Francisco Fernandez, trimis de Filip al II-lea să cerceteze ştiințific zona Mexicului în jurul anului 1558. Ambasadorul francez în Portugalia, Jean Nicot, a trimis semințe Ecaterinei de Medici, primind astfel numele Nicotiniana ${ }^{8}$. Din Spania a ajuns în Anglia, unde obiceiul fumatului din pipă este atestat în ultimul sfert al veacului al XVI-lea. Primul european care a fumat pipă a fost guvernatorul Virginiei, sir Walter Raleigh. Cu toate acestea, abia în secolul al XVII-lea obiceiul a devenit universal acceptat și practicat deopotrivă de bogați și săraci, femei și bărbați, tineri și bătrâni, ceea ce a încurajat producția de tutun și implicit de pipe. Acestea din urmă au cunoscut la rândul lor o serie de schimbări în funcție de modă, până la apariția în Franța a țigărilor în prima treime a secolului $\mathrm{XX}$.

Fumatul a fost practicat în Europa înainte de anul 1600, fiind atestat nu numai prin centrele de producere a pipelor, ci și printr-un pasaj menționat de Thomas Dallam în jurnalul său din timpul călătoriei în Turcia prin strâmtoarea Dardanele. Şi în Transilvania, studiile recente atestă faptul că obiceiul fumatului era practicat din ultimul sfert al veacului al XVI-lea, fiind adoptat din Imperiul Otoman ${ }^{9}$. Ceea ce surprinde este faptul că obiceiul fumatului din pipă a cunoscut un decalaj de câțiva ani între vestul și estul Europei, respectiv Imperiul Otoman, unde este atestat puțin mai târziu, așa cum vom vedea și în cazul de față.

Deși inițial tutunul a fost utilizat ca plantă medicinală, consumul lui a fost adoptat de către toate categoriile sociale, în comparație cu celelalte produse ,exotice” destinate comerțului (cacao, ceai sau cafea) ce proveneau de pe continentul american. În secolul al XVII-lea fumatul din pipă se generalizează și astfel tutunul devine unul dintre cele mai comercializate produse. Pe măsură ce acest domeniu economic a început să se dezvolte au apărut şi primele restricții de natură religioasă sau medicală în ceea ce privește fumatul. $\mathrm{Cu}$ toate acestea, centrele meșteşugăreşti de producere a pipelor au continuat să se dezvolte. La început, datorită faptului că tutunul era scump, pipele sunt de dimensiuni mai mici, ulterior forma și dimensiunile acestora fiind schimbate.

Așadar, încercările de a realiza studii aprofundate asupra acestor obiecte sunt încă incipiente pentru zona țărilor românești aflate în imediata vecinătate a Imperiului Otoman. Apariția în anul 2007 a unui studiu dedicat pipelor din colecția Institutului de Cercetări EcoMuzeale din Tulcea, ne-a oferit imboldul de a ne apleca asupra cercetării acestei categorii de materiale descoperite la Orașul de Floci, care fac parte din colecția Muzeului Național de Istorie a României. Demersul de faţă are în vedere studierea unui lot de pipe care au fost descoperite în timpul propriilor cercetării arheologice (cu o singură excepție nr. 16) ${ }^{10}$, dar în viitor voi extinde cercetarea și la obiectele aflate în colecția muzeului, unele provenite și din cadrul altor situri arheologice.

În general, pipele sunt realizate din caolin sau lut comun, în tipare cu două valve; decorul era realizat după îmbinarea celor douã părți și apoi erau arse. Un număr restrâns din totalul pipelor descoperite erau smălțuite. Din punct de vedere structural și tipologic pipa era formată din: găvan, bordură, gambă și inel.

\footnotetext{
${ }^{6}$ Robinson 1985 sau revista dedicată acestui tip de artefact Clay Pipe Research.

${ }^{7}$ Robinson 1985

${ }^{8}$ Robinson 1985, 150

9 Gruia 2012, 259

${ }^{10}$ Pipa a fost descoperită în cadrul cercetării necropolei nr. 5, din anul 1993, nepublicată şi care ne-a parvenit prin amabilitatea doamnei dr. Anca Păunescu, căreia îi mulțumim şi pe aceastã cale.
} 
Cele 16 pipe din lut descoperite în ultimii ani în cadrul sitului arheologic de la Orașul de Floci, își găsesc analogii în cadrul tipologiei generale realizate de către cercetătorii de la muzeul tulcean pe baza pipelor de lut de la Babadag, fapt pentru care vom reitera cele trei mari grupe ${ }^{11}$. Aceste categorii au fost stabilite de către Rebecca Robinson și reprezintã o clasificare din punctul de vedere al formei găvanului a pipelor descoperite la Corint și Atena.

Prima mare categorie, A, stabilită de specialiștii amintiți, cuprinde pipele cu găvan rotund, piciorul scurt, inel bine evidențiat și decorat. Unele piese au găvanul mai mare, decorat în relief, cu registre în care sunt incizate motive florale. Acestea au fost lucrate din caolin, cu sau fără angobă, in cazul nostru unele fiind smălțuite cu maro sau verde. Pipele smălțuite din colecția de la Babadag sunt considerate mai timpurii, iar ponderea lor este mai mică. Grupa B, conform aceleași surse, cuprinde pipele care au găvanul în formă de disc. Grupa C conține pipe cu găvanul de forma unui clopot, gamba evidențiată și inelul de formă octogonală. Unele pipe din această categorie au găvanul polifațetat.

Din cele 16 pipe întregi și fragmentare descoperite la Orașul de Floci, 13 provin din contexte arheologice certe. Astfel, pe podeaua de lut a unei locuințe cercetate în anii 2008 și $2009^{12}$, inițial într-o secțiune, apoi extinsă prin casete, au fost descoperite 8 pipe (nr. cat. 1-8), monede, un cercel şi un inel. Din punct de vedere stratigrafic și ținând cont de materialul arheologic, locuința poate fi încadrată în perioada cuprinsă între sfầrșitul secolului al XVI-lea și începutul secolului al XVII-lea. Luând în considerare numărul mare de monede, de pipe, modalitatea de construcție, fără șanțuri de bârnă laterale doar unul central ce susținea un acoperiș în două ape, funcționalitatea acestei locuințe poate fi una comercială.

Din totalul pipelor, 3 sunt fără context arheologic clar (nr. cat. 9, 14 și 15), fiind descoperite în suprafaţa arată, stratigrafia fiind afectată inclusiv pentru palierul secolului al XVII-lea. Una provine dintr-o necropolă (nr. cat. 16). Alte 3 au fost descoperite în cadrul cercetării pavimentului unui atelier de prelucrat osul (nr. cat. 10, 11 și 12), iar ultima (nr. 13) face parte din inventarul edificiului cu contraforturi, datat în secolul al XVII-lea. În ceea ce privește materialul descoperit în cadrul atelierului de prelucrat osul, pipele pot fi datate la sfârșitul secolului al XVI-lea.

Din punct de vedere tipologic, 10 pipe pot fi încadrate grupei A, 4 pot fi atribuite grupei B, iar restul (2) grupei C. Cronologic acestea datează de la sfârşitul secolului al XVI-lea și cel mult prima treime a secolului următor pentru pipele descoperite în complexe arheologice clare, respectiv cel mult până în a doua jumătate a secolului al XVII-lea pentru restul.

O analiză amănunțită, precum și studierea altor pipe din colecția muzeului (cele mai numeroase fiind tot cele provenite de la Orașul de Floci) ne vor permite un studiu detaliat, articolul de față încercând să introducă în circuitul științific doar o parte din această categorie de materiale arheologice. Faptul că pipele analizate provin din cercetarea arheologică a sitului medieval ne permite o datare mai bună a lor, informațiile tipologice fiind coroborate cu alte elemente de datare (poziția stratigrafică sau moneda). Una dintre concluziile preliminare ale studiului pipelor descoperite pe în cadrul acestui sit constă în faptul că acestea pot fi datate la sfârșitul secolului al XVI-lea, în condițiile în care pipele de la Atena și Corint sunt atestate la începutul secolului următor. Un alt aspect de remarcat este acela că ponderea pipelor smălțite este mai mică în Imperiul Otoman, acestea fiind considerate mai timpurii, în timp ce la Orașul de Floci prezența lor este mai numeroasă.

\footnotetext{
11 Costea, Stănică, Ignat, 2007

${ }^{12}$ Păunescu et alii 2010
} 
CATALOG $^{13}$

1. Pipă fragmentară, inv. MNIR $338540, \mathrm{~L}=5,2$ $\mathrm{cm}, \mathrm{H}=3,1 \mathrm{~cm}, \mathrm{Dg}=2,2 \mathrm{~cm}, \mathrm{Di}=2 \mathrm{~cm}$, lucrată din caolin cu angobă de culoare crem, găvan cilindric, gambă simplă decorată cu câteva linii incizate care se îngroașă în formă de inel. Datare: secolele XVI-XVII; grupa A (PI. I/1)

2. Pipă fragmentară, inv. MNIR 338541, $\mathrm{L}=5,2$ $\mathrm{cm}, \mathrm{H}=3,1 \mathrm{~cm}, \mathrm{Dg}=2,2 \mathrm{~cm}, \mathrm{Di}=2 \mathrm{~cm}$, lucrată din caolin cu angobă de culoare crem, cu găvan cilindric, gambă simplă decorată cu câteva linii incizate care se ingroașă în formă de inel. Datare: secolele XVI-XVII; grupa A (PI. I/2)

3. Pipă, inv. MNIR $338542, \mathrm{~L}=6,2 \mathrm{~cm}, \mathrm{H}=1,9$ $\mathrm{cm}, \mathrm{Dg}=3,1 \mathrm{~cm}, \mathrm{Di}=2,3 \mathrm{~cm}$, lucrată din caolin cu urme de ardere secundară, găvanul în formă de disc, bordură spartă, gamba scurtă şi inel evidențiat. Găvanul este decorat pe partea inferioară în formă de scoică, fiecare lob fiind evidențiat printr-un şir de linii realizat cu roata dințată, iar în mijloc o floare cu șase petale. Floarea se regăsește pe capătul fiecărui lob din partea superioară a gambei (nouă). Jumătatea gambei dinspre inel este decorată cu un brâu bombat, delimitat de inel şi de cealaltă jumătate printr-un şir de linii realizate cu roata dințată. Partea bombată este decorată cu două registre de șiruri de litere "S" răsturnate delimitate între ele tot de două linii realizate cu roata dințatã. Jumătatea dinspre găvan nu prezintã decor dar este alveolată. Datare: secolele XVI-XVII; grupa B (PI. I/3)

4. Pipă, inv. MNIR 338543, $\mathrm{L}=4,6 \mathrm{~cm}, \mathrm{H}=2,3$ $\mathrm{cm}, \mathrm{Dg}=2,6 \mathrm{~cm}, \mathrm{Di}=1,5 \mathrm{~cm}$, de mici dimensiuni din caolin cu găvanul rotund şi gamba scurtă. Pe bordură are un decor de linii verticale realizate cu rotița dințată. Mijlocul gambei are decorat cu un șir de puncte incizate. Inelul este bine evidențiat, având același șir de puncte la capătul exterior. Pe partea inferioară a găvanul este incizat un decor în forma literei $\mathrm{V}$ cu deschiderea spre inel. Datare: secolele XVIXVII; grupa A (PI. I/4)

5. Pipă fragmentară, inv. MNIR $338544, \mathrm{H}=3,4$ $\mathrm{cm}, \mathrm{Dg}=3,4 \mathrm{~cm}$, lucrată din caolin cu angobă roșiatică din care se păstrează doar găvanul. Găvanul în formă de disc cu o bordură înaltă. Decor elaborat din motive incizate. Partea inferioară este decorată cu 5 frunze iar spre partea superioară sunt incizate 3 registre cu rotița dințată. Registrul inferior are incizate linii verticale cu rotița dințată care are la capete forma unor frunzulițe. Următorul registrul nu

13 Abrevieri: $\mathrm{L}=$ lungime; $\mathrm{H}=$ înălțime; $\mathrm{Dg}=$ diametru găvan; $\mathrm{Di}=$ diametru inel. prezintă $n$ decor, pentru ca ultimul registru, al bordurii să aibă incizate 8 motive florale. Piesa prezintă urme de ardere secundară. Datare: secolele XVI-XVII; grupa C (PI. II/1)

6. Pipă, inv. MNIR 338545, $\mathrm{L}=4,2 \mathrm{~cm}, \mathrm{H}=2$ $\mathrm{cm}, \mathrm{Dg}=3 \mathrm{~cm}, \mathrm{Di}=1,8 \mathrm{~cm}$, lucrată din caolin cu angobă de culoare neagră, cu găvanul în formă de disc lobat, gamba scurtă, cu inel bine evidențiat şi decorat cu linii oblice. Pe partea superioară a găvanului decorul este realizat, pe fiecare din cei cinci lobi, din dreptunghiuri cu linii incizate verticale și orizontale de forma unor pătrate. Partea inferioară a găvanului este decorată şi ea cu acelaşi dreptunghi împărțit în pătrățele. Datare: secolele XVI-XVII; grupa B (PI. II/2)

7. Pipă fragmentară, inv. MNIR 338546, $\mathrm{H}=$ $2,4 \mathrm{~cm}, \mathrm{Dg}=3,2 \mathrm{~cm}$, lucrată din caolin cu angobă de culoare neagră din care se păstrează doar găvanul, amplu decorat. Găvanul este în formă de stea (şase colțuri) pe partea inferioară fiind decorat ca o ştanță Steaua lui David, diferența între nivelul superior și decorul propriu-zis fiind de aprox. $3 \mathrm{~mm}$. De jurîmprejurul găvanului se găsesc cinci registre verticale, corespunzătoare stelei (al 6-lea fiind gamba) delimitate de câte două linii excizate care au în centru o proeminență de formă ovală. Datare: secolele XVI-XVII; grupa C (PI. II/3)

8. Pipă, inv. MNIR $338549, \mathrm{~L}=5,2 \mathrm{~cm}, \mathrm{H}=3,5$ $\mathrm{cm}, \mathrm{Dg}=3,1 \mathrm{~cm}, \mathrm{Di}=2 \mathrm{~cm}$, lucrată din caolin cu smalț de culoare muștar, cu găvan în formă de scoică şi bordură cilindrică, gamba scurtă și inel bine evidențiat. Decorul bordurii este împărțit în două registre, primul fiind realizate din două șiruri de linii în zig-zag, iar cel superior din linii verticale. Inelul este decorat cu linii oblice. Datare: secolele XVI-XVII; grupa B (PI. II/4)

9. Pipă, inv. MNIR $338658, \mathrm{~L}=5,2 \mathrm{~cm}, \mathrm{H}=3,5$ $\mathrm{cm}, \mathrm{Dg}=3,1 \mathrm{~cm}, \mathrm{Di}=2 \mathrm{~cm}$, lucrată din caolin cu gãvan cilindric, gambă simplă fără decor se îngroașă în formã de inel bine conturat. Datare: secolul al XVII-lea; grupa A (PI. III/1)

10. Pipă fragmentară, inv. MNIR 338659, L = $3,3 \mathrm{~cm}, \mathrm{Di}=1,5 \mathrm{~cm}$, lucrată din caolin cu angobă neagră. Se păstrează doar gamba şi inelul simplu evidențiat de o zonă îngroșată a gambei. La mijlocul gambei prezintă un decor dintr-o linie circulară. Datare: secolele XVIXVII; grupa A (PI. III/2)

11. Pipă fragmentară, inv. MNIR $338660, \mathrm{~L}=4$ $\mathrm{cm}, \mathrm{Di}=1,8 \mathrm{~cm}$, lucrată din caolin cu angobã neagră. Se păstrează doar gamba și inelul simplu. La mijlocul gambei prezintă un decor dintr-o linie circulară excizată care delimitează un registru îngroșat, până la inel, decorat cu linii 
verticale incizate. Datare: secolele XVI-XVII; grupa A (PI. III/3)

12. Pipă fragmentară, inv. MNIR $338661, L=$ $3,3 \mathrm{~cm}, \mathrm{Di}=1,7 \mathrm{~cm}$, lucrată din ceramică roșiatică cu gamba scurtă și inel simplu evidențiat de o zonă îngroșată. Datare: secolele XVI-XVII; grupa A (Pl. III/4)

13. Pipă fragmentară, inv. MNIR 338662, $L=$ $4,1 \mathrm{~cm}, \mathrm{H}=2,5 \mathrm{~cm}, \mathrm{Dg}=3 \mathrm{~cm}, \mathrm{Di}=2,2 \mathrm{~cm}$, lucrată din caolin cu angobă roşie ce are găvanul în formă de disc turtit și gamba scurtă. Inelul este scurt fiind urmat de o zonă îngroșată a gambei. Decorul pe partea inferioară a găvanului este reprezentat de două linii în formă literei „V”, incizate, deschise spre inel care profilează gamba. De jur-împrejurul găvanului decorul este compus dintr-o linie circulară incizată care are deasupra un şir de cercuri fiecare având un punct în mijloc. Datare: secolul al XVII-lea; grupa A (PI. IV/1)

14. Pipă, inv. MNIR $338663, \mathrm{~L}=5,1 \mathrm{~cm}, \mathrm{H}=3$ $\mathrm{cm}, \mathrm{Dg}=2,2 \mathrm{~cm}, \mathrm{Di}=1,8 \mathrm{~cm}$, lucrată din ceramică roşiatică cu găvan bitronconic şi bordură cilindrică înaltă, gambă scurtă şi inel subțire. Decorul găvanului este reprezentat de două flori cu cinci petale dispuse de o parte și de alta, iar al gambei din şapte ovale incizate. Piesa are smalț maro. Datare: secolul al XVIIlea; grupa B (PI. IV/2)

15. Pipă fragmentară, inv. MNIR 338664, $L=$ $3,3 \mathrm{~cm}, \mathrm{Di}=2 \mathrm{~cm}$, lucrată din caolin din care se păstrează jumătate din gambă și inelul bine evidențiat de un şanț în care sunt înfăşurate cinci fire metalice, urmând după 0 zonă îngroșată a gambei delimitată de o linie incizată circulară. Datare: secolul al XVII-lea; grupa A (Pl. IV/3)

16. Pipă fragmentară, inv. MNIR 338665, $\mathrm{L}=5$ $\mathrm{cm} ; \mathrm{H}=2,3 \mathrm{~cm}, \mathrm{Dg}=2,2 \mathrm{~cm}, \mathrm{Di}=2 \mathrm{~cm}$, lucrată din lut cu găvanul rotund, bordura ruptă. Gamba scurtă decorată cu şase linii excizate. Gamba este separată de inel de o linie excizată în zigzag. Pe exterior găvanul este decorat de o parte şi de alta cu câte o floare cu şase petale goale, iar pe spate cu o floare cu şapte petale pline şi o frunză ce merge spre marginea găvanului. Întregul exemplar acoperit cu smalţ de culoare verde-oliv. Datare: secolul al XVIIlea; grupa A (PI. IV/4)

\section{BIBLIOGRAFIE}

Chiţescu et alii 1979

Chiţescu et alii 1981

Chifescu et alii 1982

Chițescu, Păunescu 1986

Chiţescu, Păunescu,

Papasima 1983

Costea, Stănică, Ignat, 2007

Costea-Ene 2003-2004

Gruia 2012

Lungu 1981

Păunescu 2000

Păunescu 2001
L. Chițescu, N. Conovici, R. Lungu, A. Păunescu, V. Rădulescu, Cercetări arheologice la Piua Petrii (Oraşul de Floci), jud. Ialomiţa, $C A$, III, 1979, p. 199-241

L. Chiţescu, R. Lungu, T. Papasima, P. Vlădilă, V. Rădulescu, A. Păunescu, Cercetări arheologice în anul 1979 la Piua Petri (Oraşul de Floci), comuna Giurgeni, jud. Ialomiţa, $C A$, IV, 1981, p. 120-143

L. Chiţescu, T. Papasima, P. Vlădilă, Venera Rădulescu, Anca Păunescu, Cercetările arheologice de la Piua Petrii (Oraşul de Floci), jud. Ialomiła, $C A, \mathrm{~V}, 1982$, p. 129-168

L. Chiţescu, A. Păunescu, Cercetările arheologice de la Piua Petri (Oraşul de Floci), com. Giurgeni, jud. Ialomiţa, $C A$, VIIl, 1986, p. 75-83

L. Chifescu, A. Păunescu, T. Papasima, Cercetări arheologice de la Piua Petri (Oraşul de Floci), jud. Ialomiţa, $C A$, VI, 1983, p. 95-108

I. Costea, A. Stănică, A. Pipele de lut descoperite la Babadag, Peuce S.N, V, 2007, p. 335-362

I. Costea-Ene, Un cuţit de plug descoperit la Oraşul de Floci (Piua Petri), comuna Giurgeni, judeţul Ialomiţa, Ialomiţa, IV, 2003-2004, p. 241-246

A-M. Gruia, Pipele de la Reghin, Apulum, XLIX, 2012, seria Historia and Patrimoniu, p. 259-280

R. Lungu, Contribuții la istoria meşteşugurilor medievale în Tara Românească, Revista de Istorie, 1981, 34, nr. 3, p. 513-519

Anca Păunescu, Cu privire la boierii de la Oraşul de Floci în secolele XVIXVII, $M N$, XII, 2000, p. 25-32

A. Păunescu, Informaţii documentare privind aşezămintele religioase de la Oraşul de Floci, Muzeul Nafional, XIII, 2001, p. 15-20 
Păunescu 2003

Păunescu 2005

Păunescu

et alii 2007-2008

Păunescu et alii 2010

Robinson 1985
A. Păunescu, Un sat dispărut - Blagodești, Muzeul Național, XV, 2003, p. $37-43$

Anca Păunescu, Oraşul de Floci. Un oraş dispărut din Muntenia medievală, Târgovişte, 2005

A. Păunescu, I. Ene, D. Mihai, Ghe. Matei, G. Vasile, Cercetări arheologice în vatra Oraşului de Floci (Piua Petri), comuna Giurgeni, judeţul Ialomiţa. campaniile din anii 2006-2007, CA, XIV-XV, 2007-2008, p. 11-44

A. Păunescu, Irina Ene, Dana Mihai, Ghe. Matei, R. Coman, Cercetări arheologice în vatra Orașului de Floci (Piua Petri), comuna Giurgeni, județul Ialomița. Campaniile din anii 2008-2009, CA, XVII, 2010, p. 225240

R. C. W. Robinson, Tobacco pipe of Corint hand of the Athenian Agora, Hesperia, 54, 2, p. 149-203

Restaurarea pieselor: Gabriela Dragomir

Foto: George Nica

Desen: Georgiana Ducman

IRINA ENE

Muzeul Naţional de Istorie a României, Secției de Arheologie Pre- şi Protoistorică, Clasică şi Medievală irinaene29@yahoo.com 


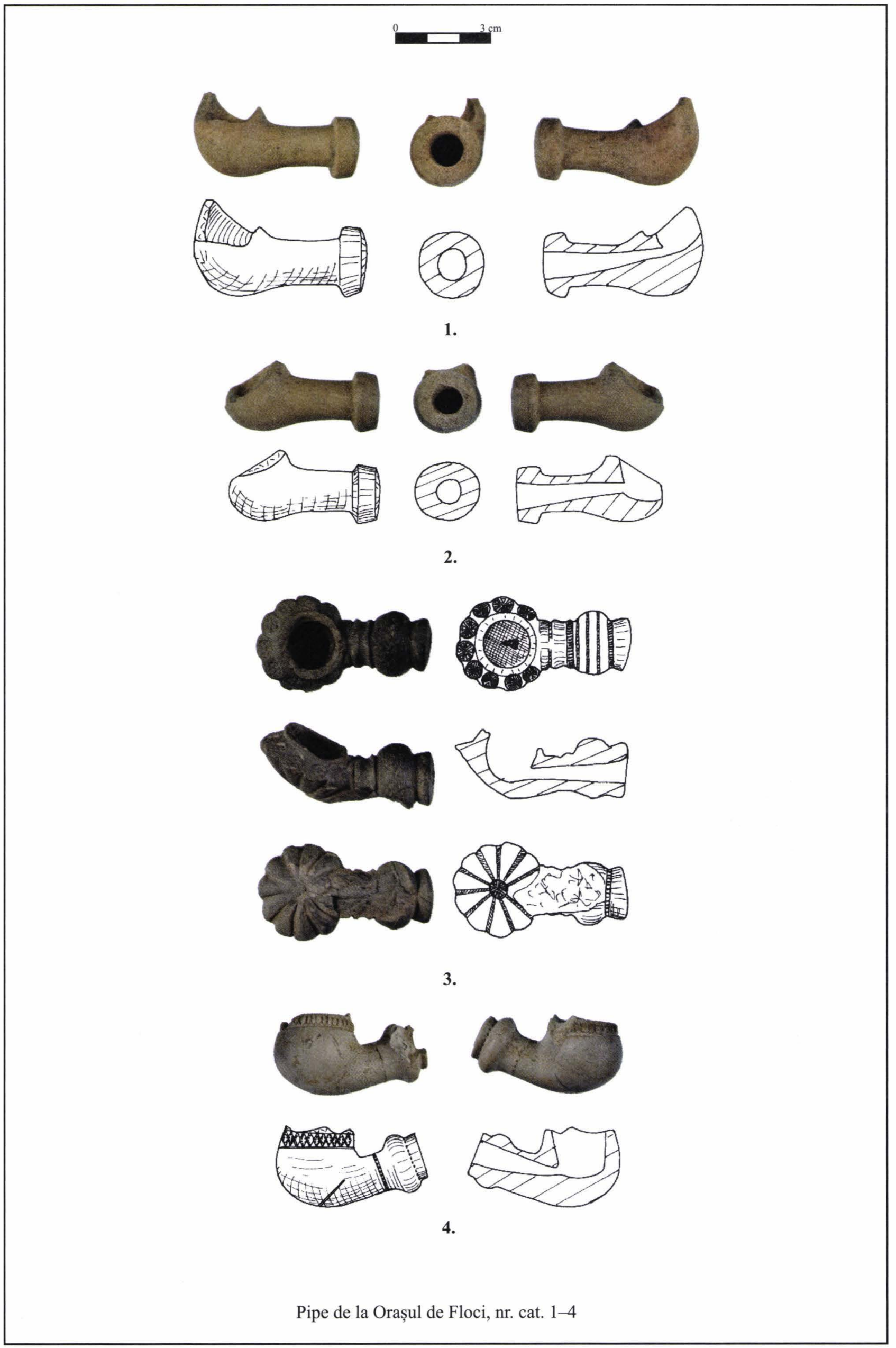

PI. II 


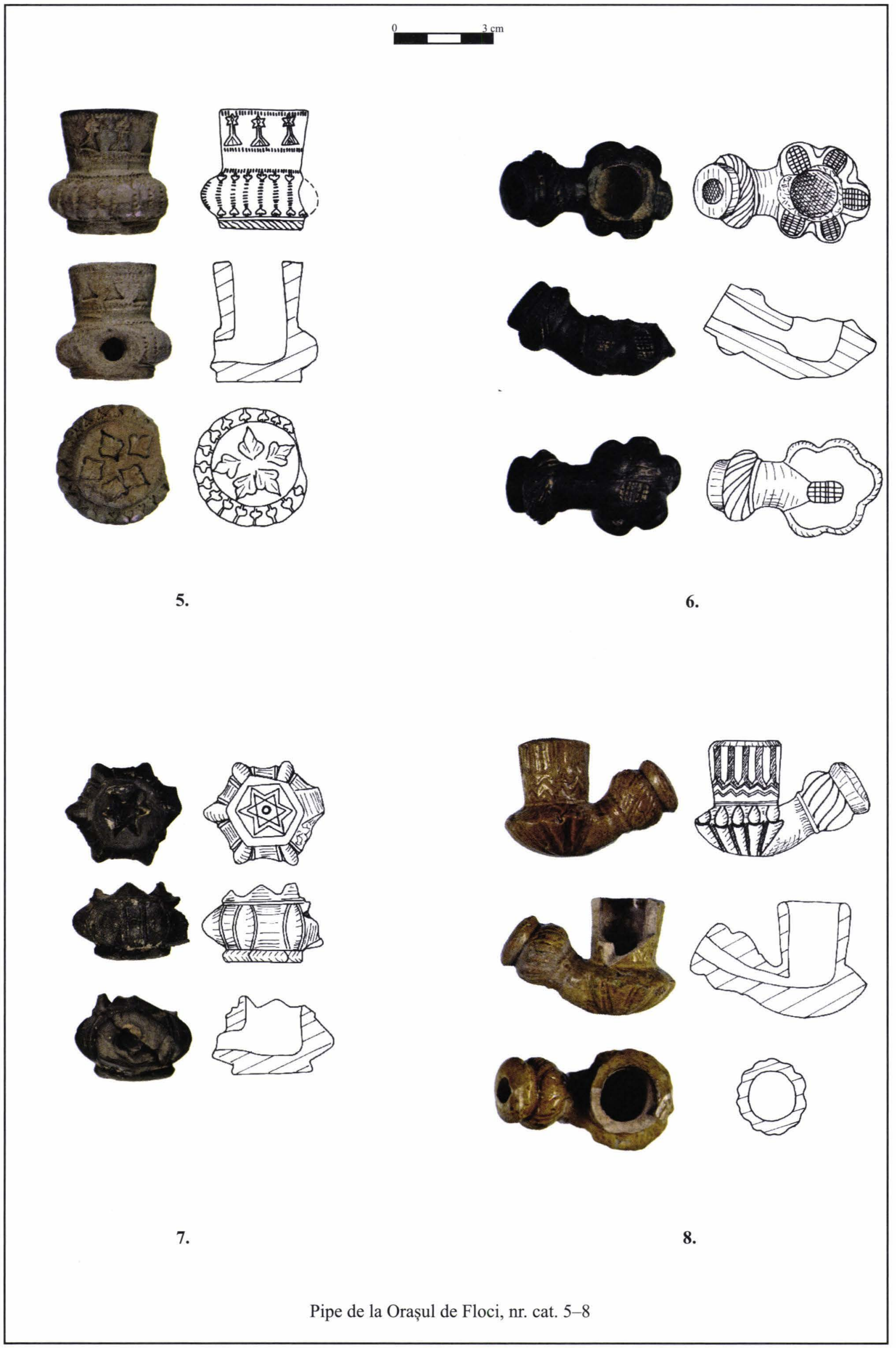

PI. II 


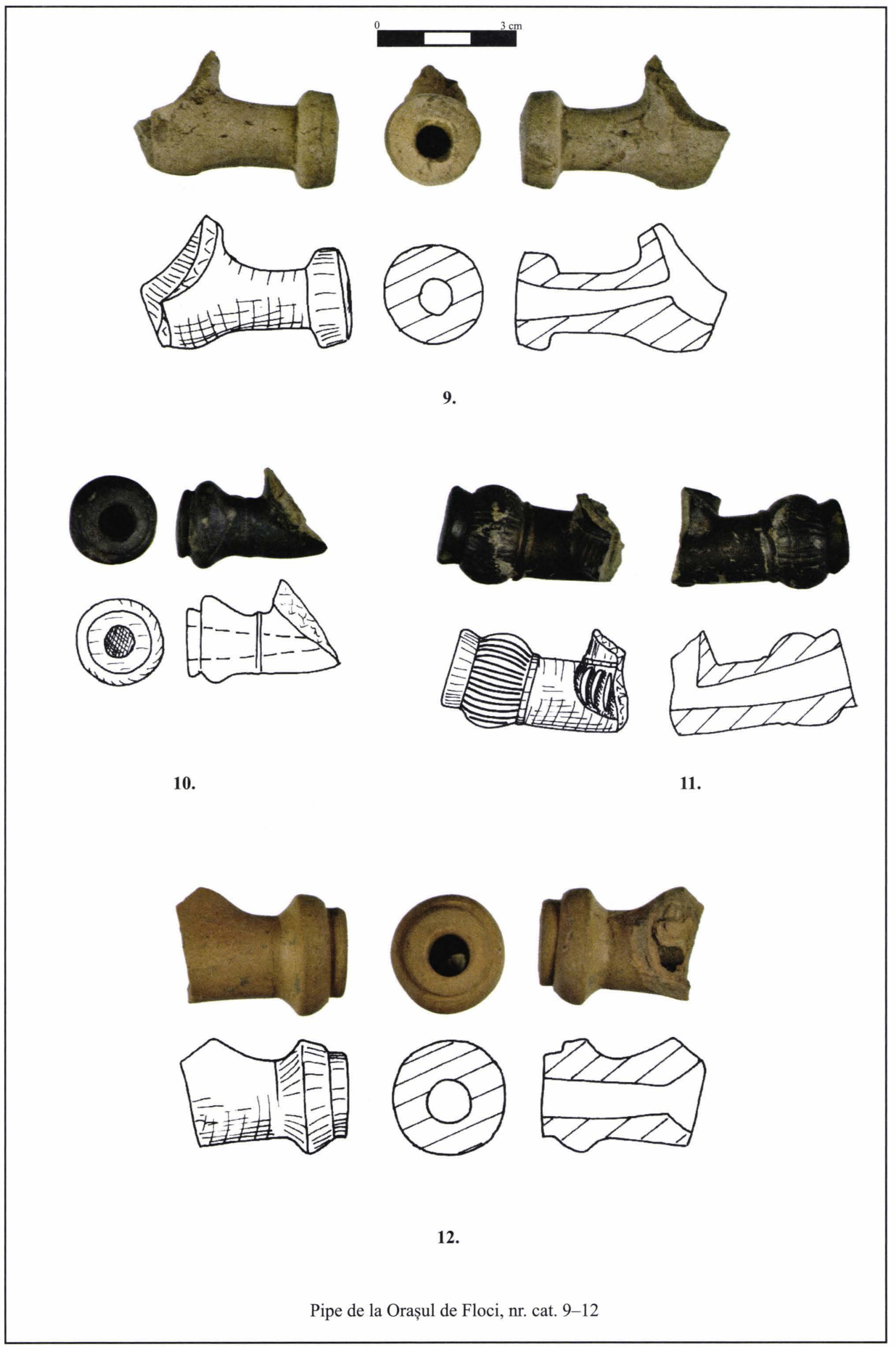

Pl. III 


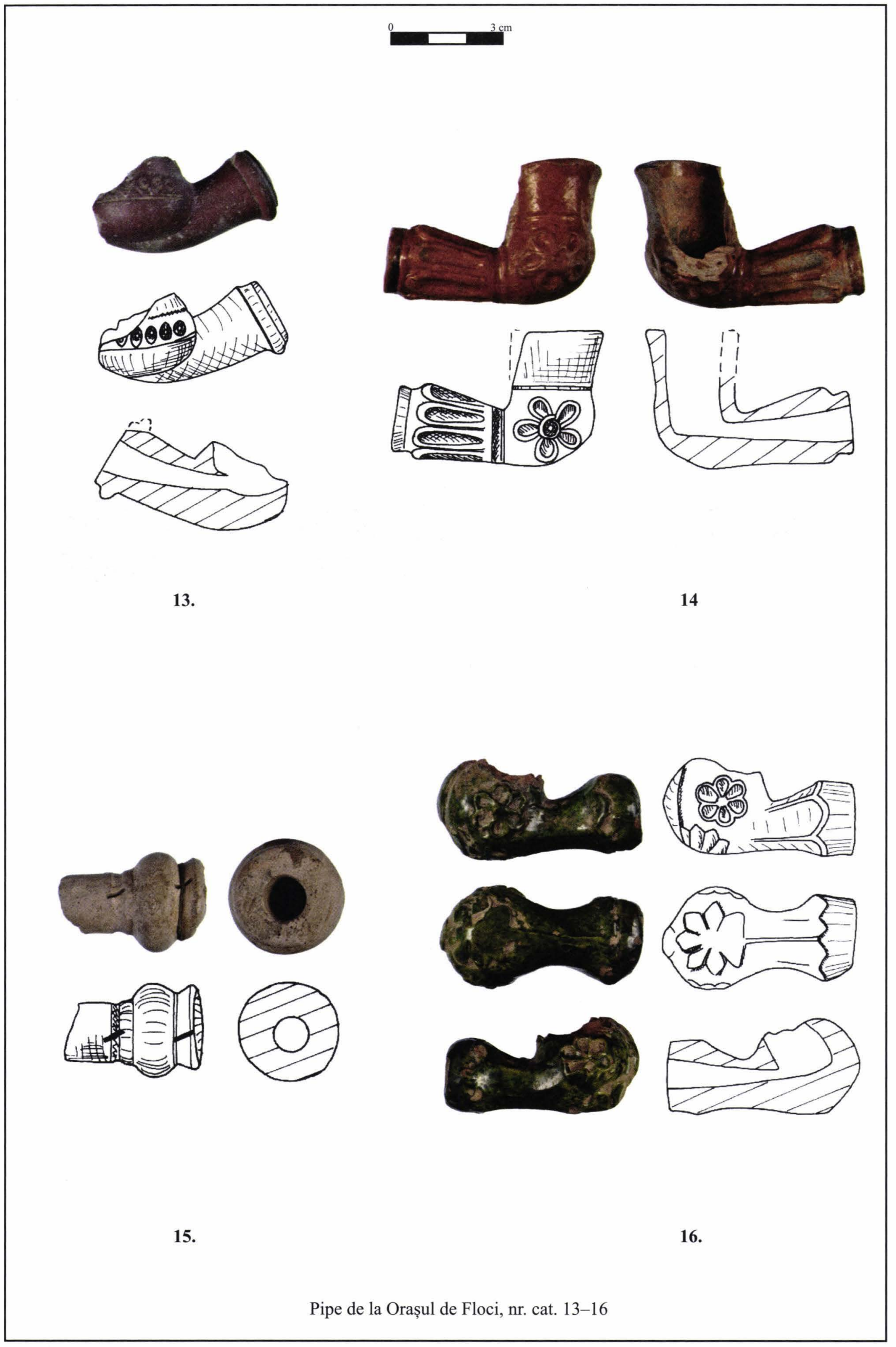

PI. IV 